\title{
HISTOLOGICAL AND STEREOLOGICAL STUDY ON THE KIDNEYS IN SPARROWS LIVING IN WET AND ARID ZONES
}

\author{
MahnazRezaei', Zahra Masoumi', Abolghasem Nabipour ${ }^{1 *}$, Mohammad Azizzadeh², Morteza Behnam-Rasouli \\ ${ }^{1}$ Department of Basic Sciences, ${ }^{2}$ Department of Clinical Sciences, Faculty of Veterinary Medicine, ${ }^{3}$ Department of Biology, Faculty of \\ Sciences, Ferdowsi University of Mashhad, Mashhad 9177948974, Iran \\ ${ }^{*}$ Corresponding author, E-mail: nabipour@um.ac.ir
}

\begin{abstract}
The structure of the kidneys of sparrows living in wet and arid zones was compared to each other. A stereological study was conducted to quantify the components of the bird's kidneys. A total of 10 female sparrows living in wet and arid zones were collected. The length of the kidneys was measured before blocking. The transverse serial sections were taken with a thickness of $5 \mu \mathrm{m}$. The sections were stained with haematoxylin and eosin (H\&E) as well as periodic acid Schiff-alcian blue (PAS-AL).

The kidneys of the sparrows consisted mostly of a cortex with only a small portion as medulla. The medulla was arranged in the form of cones with different lengths, which were randomly distributed within the kidney. The medullary nephron tubules were arranged sequentially. Thick and thin limbs of loop of Henle were separated by the collecting ducts. The histological structure and absolute volumes of the kidneys and components of the nephron were quantified. The absolute volumes of the structures within the right and left kidneys were not significantly different. The volume of the whole kidney $(p<0.001)$ in the wet zone was larger than that in the arid zone. Furthermore, the volume proportion of the proximal tubule as well as cortex to whole kidney size was higher than that in wet zone birds. Whereas, the volume proportion of the medulla, distal tubule, cortical collecting tubule, medullary collecting duct and thin limb of loop of Henle to whole kidney size was higher than that in arid zone birds $(p \leq 0.001)$. This feature indicates that the arid zone bird species had a more high ability to conserve water by producing concentrated urine.
\end{abstract}

Key words: sparrow; stereology; histology; kidney; environment

\section{Introduction}

Many detailed studies have been published concerning the histology of the mammal's kidney, but comparatively, few studies have been conducted into the bird's kidney. The nephron is the functional unit of the kidney and its structure considerably varies between the different vertebrates. Birds and mammals produce hyperosmotic urine due to presence of a loop of Henle. In birds, most nephrons do not contain a

Received:23May 2018

Accepted for publication: 9 July 2019 loop of Henle, and are referred to as the reptile type of nephrons. In mammals, all the nephrons contain a loop of Henle, but some of them are long and the others are short (1).

Bird inhabiting arid and wet environments have a different diet. To accommodate dietary variations available water and ions, the kidney structure may be expected to vary in birds inhabiting two completely different climatic regions (2). In the avian kidney, the cortex and medulla are arranged in a series of randomly distributed and oriented cones. The avian kidney has both looped and loopless nephrons (3). The ability to conserve ions and/or water may be correlated with the 

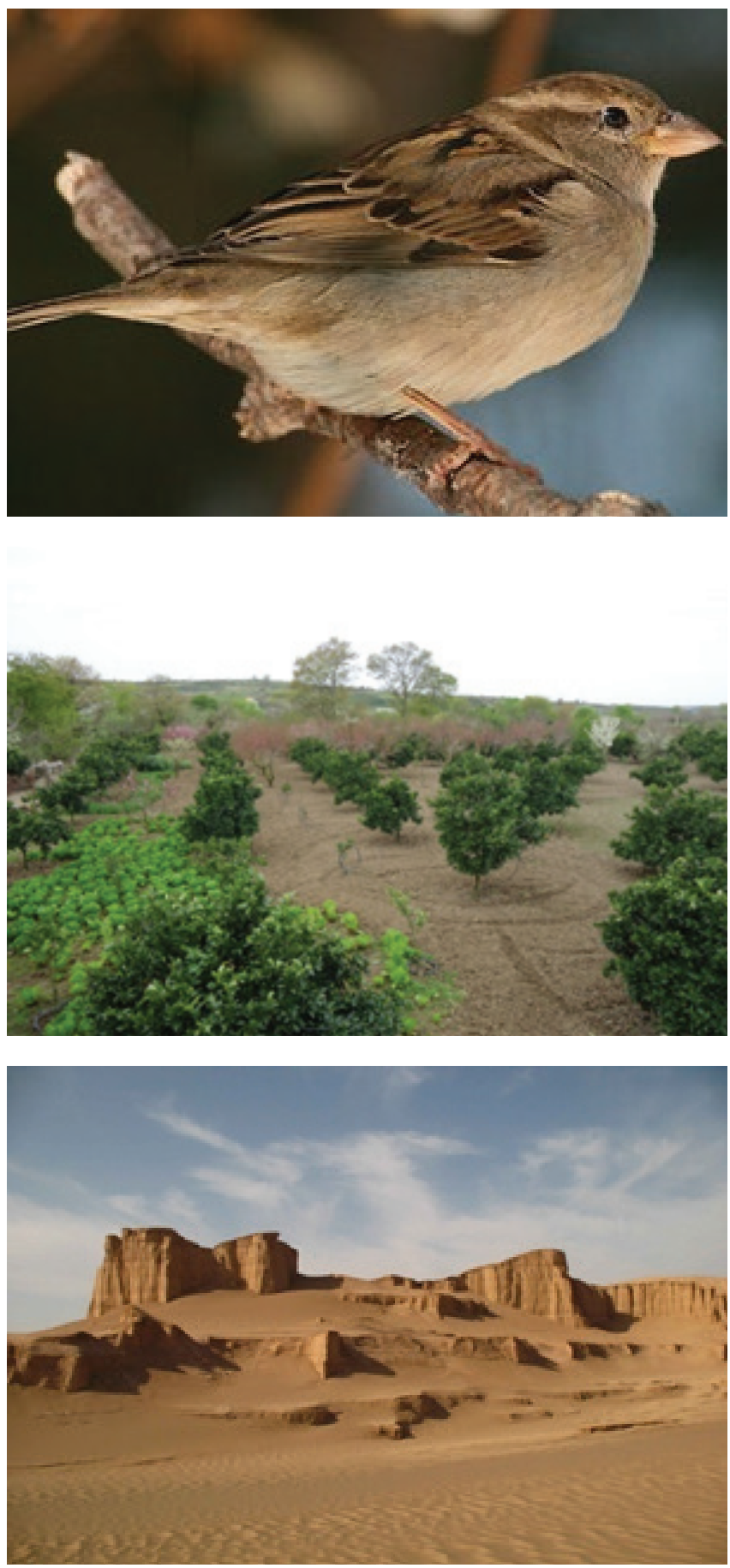

Figure 1: Sparrow and the environments of sampling

structure of the nephron. The present study aimed to quantitatively investigate differences in the anatomical structure of the kidneys from sparrows living in either arid or wet zone areas. In addition, the physiological importance of each component of nephron will be discussed. The data can be used in various fields of science, such as histology, biology, physiology and ecology.

\section{Material and methods}

Ten adult sparrows (Passer domesticus) were collected from arid and wet zones (5 of each). Shahdad area (Kerman province, Iran) as an arid zone and Qaem Shahr city (Mazandaran province, Iran) as a wet zone were chosen (Fig. 1). The captured birds were accidentally females. All the experiments were conducted by the guidelines provided by Animal Care Committee, Ferdowsi University of Mashhad, and in compliance with the regulations formulated by the Faculty of Veterinary Medicine, Ferdowsi University of Mashhad, Iran (Grant No. 3.28795, 3.28801).

\section{Light microscopy}

The birds were euthanized with an intraperitoneal injection of barbiturate. Both right and left kidneys were removed from the synsacrum bone. The kidneys were flushed with normal saline and were fixed in $10 \%$ neutral buffered formalin for 71 hours. Tissue samples were then dehydrated and cleared by a series of graded alcohols, xylene and eventually embedded in paraffin (Merck; Darmstadt, Germany). Paraffin sections at $5 \mu \mathrm{m}$ thickness were cut from the cranial division of kidney toward the caudal division. The sections were stained with haematoxylin and eosin $(\mathrm{H} \& \mathrm{E})$ and periodic acid Schiff- alcian blue (PAS-AL) for histological observation. The latter stain was necessary to distinguish the cortical collecting tubules from the distal tubules, since the lumen of the cortical collecting tubules stains blue due to presence of mucus (4). The detailed histology of the kidney was studied. Microphotographs were taken by a CX21 light microscope (Olympus; Japan) equipped with an Olympus (U-TVO 63XC) camera.

The stereology was used to quantify the components of birds' right and left kidney. For this purpose, the overall length of each kidney from the cranial pole to the caudal pole was measured before blocking. The tissue was cut in an unbiased manner at 10 equally spaced intervals along its entire length (5). Afterward, it was sectioned at a thickness of $5 \mu \mathrm{m}$ using an RM2145 microtome (Leica; Germany).

According to the systematic random sampling (SRS) method, at least 11 sections were taken from each of the kidneys. By following the staining sections with PAS-Al, several fields from each 
section were selected (according SRS) and imaged by a photomicroscope. More than 50 images were recorded for each of the kidneys. The images were placed under a stereological grid with 300 intersection points without any directing. The point counting using the Cavalieri principle was employed to estimate the volume of the kidney, cortex, medulla, glomerulus, proximal tubule, distal tubule, and the loop of Henle and medullary ducts (6). The volume of each part of the nephrons was estimated using the formula:

$$
V=\frac{\sum p \times a(p) \times t}{M^{2}}
$$

Where $\mathrm{V}$ is the volume of the component measured by the Cavalieri principle, $\Sigma p$ is the total counted points, $a(P)$ is the reference area, $t$ is the interval between the sections and $M^{2}$ is the magnification to the power of 2 .

\section{Statistics}

The mean and standard deviation (SD) of the absolute volume of the structures within the kidneys and proportion of each structure to the whole size of the kidneys were reported. Pair sample t-test was used to compare the volume of the structures within the right and left kidneys. Moreover, the volume of the structures within the kidneys and proportion of them to the whole size of the kidney was compared in wet and arid zone birds using the independent sample t-test. All of the statistical procedures were performed using the IBM statistics software (IBM Corporation, Armonk, NY, Version 21).

\section{Results}

Histologically, the sparrows' kidneys consisted of two zones, the cortex and the medulla.

The sparrows' kidney consisted mostly of a cortex with only a small portion as medulla (Fig. 2A, B).

Using a light microscope, there were no differences between the mammalian and reptilian types of nephrons in wet and arid birds. A majority of the nephrons did not have a loop of Henle, and were always only in the cortex area. Most nephron tubules were randomly distributed within the cortex, except for the glomeruli, which were placed

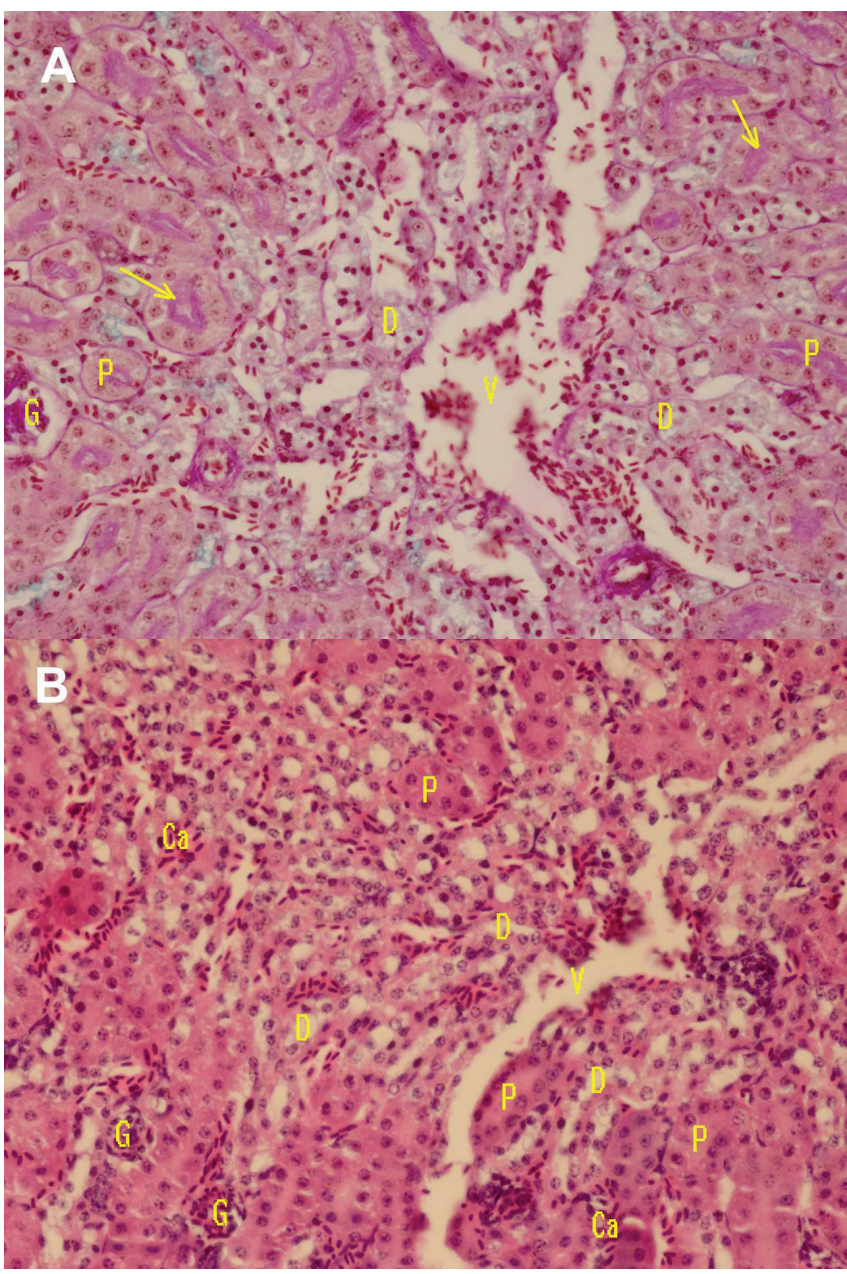

Figure 2: Photomicrograph of the kidney in transverse section of sparrows living in arid (A) and wet (B) zones. Cortex (C); medullary cone (MC); intralobular vein (V), $(\mathrm{PAS}-\mathrm{AL} \times 200,160)$

most commonly in the peripheral cortex, and a majority of distal tubules were clustered around the intralobular vein (Fig. 3A, B).

The renal corpuscle consisted of an outer Bowman's capsule separated from glomerulus by Bowman's space. The glomeruli consisted of a packed central core of mesangial cells surrounded by capillary loops (Fig. 3B). Both mammalian and reptilian types of glomerules were studied. The proximal and distal tubules were covered by the cuboidal epithelium. The macula densa was not developed in the sparrows. The luminal surface area of the proximal tubule was enhanced by a thick layer of microvilli forming a brush border (Fig. 3, 4). The cortical collecting tubules were covered by the cuboidal epithelium. The cytoplasm of cell contained a basal nucleus and mucopolysaccharides. The mucopolysaccharide was stained with PAS-AL (Fig. 4). 

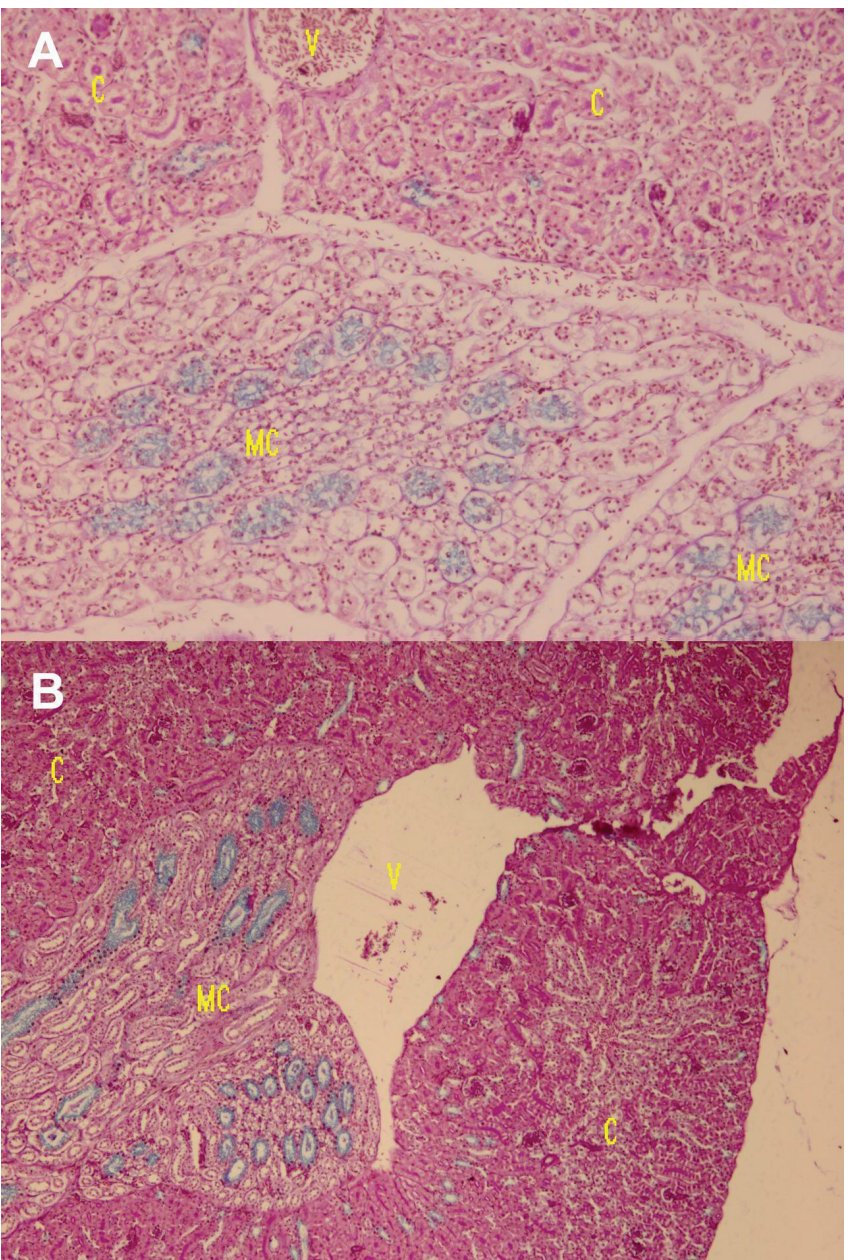

Figure 3: Photomicrograph of the kidney of sparrows living in arid (A) and wet (B) zones, showing the concentric arrangement of distal tubule (D) around the intralobular vein (V). Proximal tubule $(\mathrm{P})$; glomerolus $(\mathrm{G})$; brush border (arrows), (PAS-Al $\times$ 400, 640)

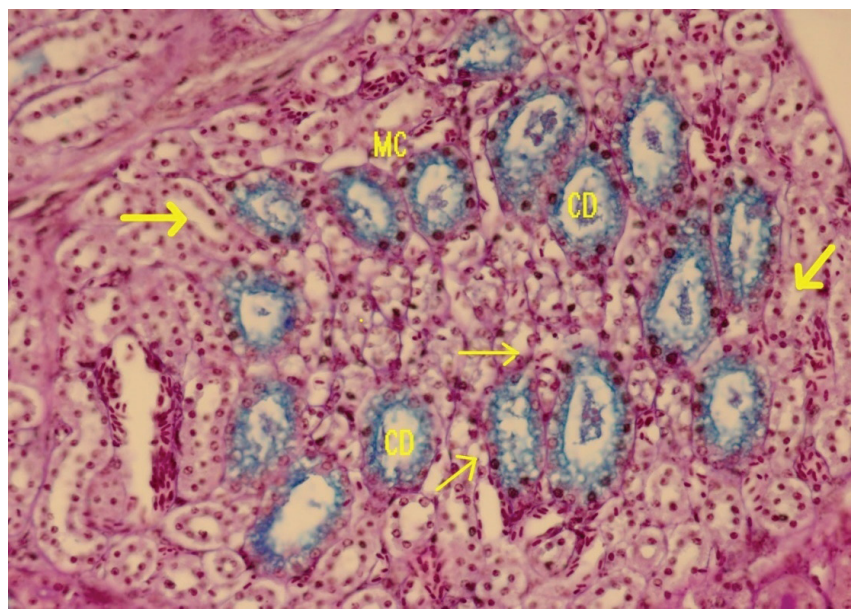

Figure 4: Photomicrograph of the kidney of sparrows living in arid zone. Proximal tubule (P); cortical collecting tubule (CC); glomerolus $(\mathrm{G})$; intralobular vein $(\mathrm{V})$; brush border (arrows), (PAS-Al × 400)

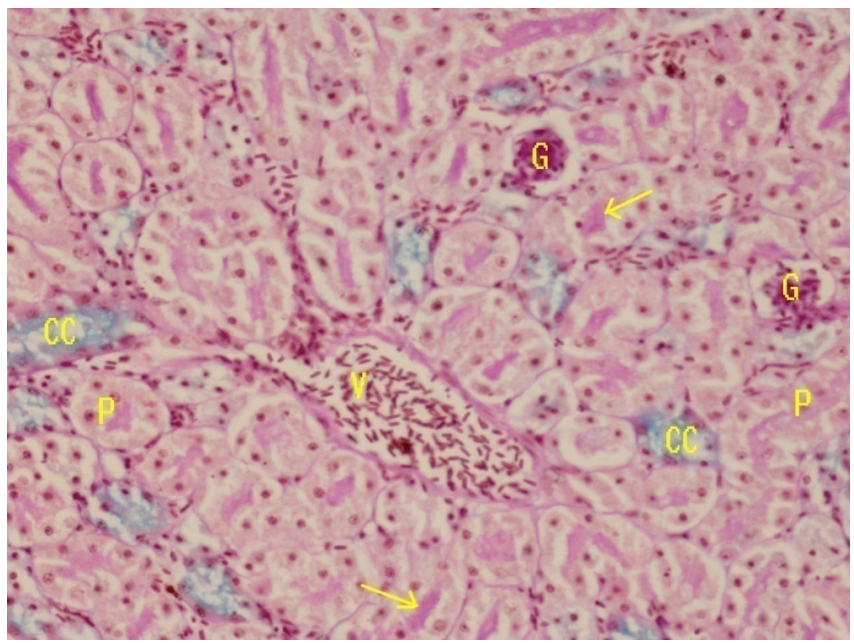

Figure 5: Photomicrograph of the medullary cone (MC) in the kidney of sparrows living in wet zone the wet zone sparrow's kidney, showing the arrangement of tubules within the cone. Thick limb of loop of Henle (thick arrows); medullary collecting ducts (CD), thin limb of loop of Henle (thin arrows) $(\mathrm{H} \& \mathrm{E} \times 640)$

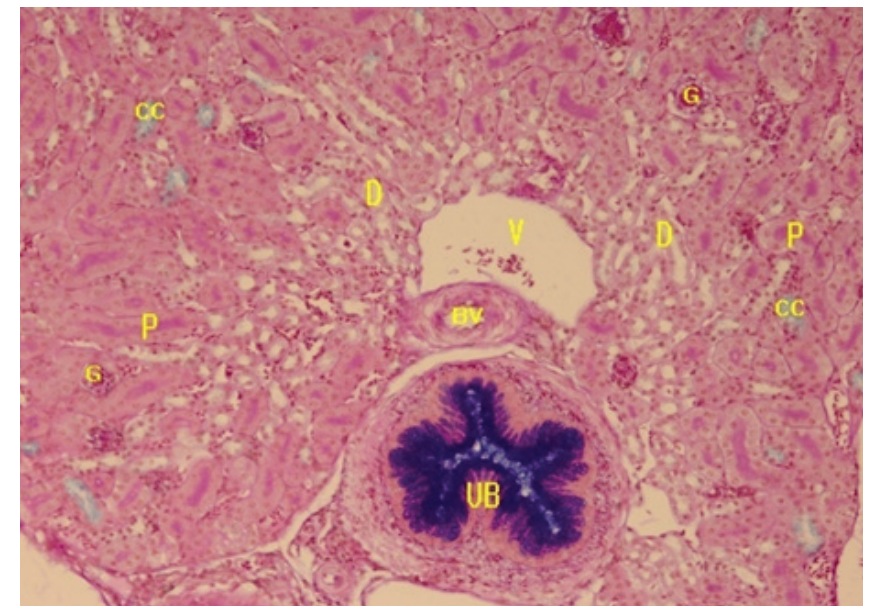

Figure 6: Showing the proximal tubule $(\mathrm{P})$; distal tubule (D); cortical collecting tubule (CC); glomerolus (G); blood vessel (BV); intralobular vein (V) and an ureteric branch (UB) in the kidney of sparrows living in wet zone wet zone sparrow's kidney, (PAS-Al × 320)

Medullary nephron tubules were arranged sequentially. Thick and thin limbs of loop of Henle were separated by the collecting ducts. Thick limbs were limited to the periphery of the medullary cone and surrounded a ring of collecting ducts, which in turn surrounded some thin limbs. The thin and thick limbs of loop of Henle were covered by the simple cuboidal epithelium. The cortical collecting duct continued into the medulla as the medullary collecting duct. The medullary collecting duct consisted 
Table 1: Description of the absolute volumes $\left(\mathrm{mm}^{3}\right)$ of the left $(n=5)$, right $(n=5)$ and total $(n=10)$ structures of the kidney in wet and arid zone birds

\begin{tabular}{|c|c|c|c|c|c|c|c|c|c|}
\hline \multirow[t]{2}{*}{ Component } & & \multicolumn{4}{|c|}{ Arid zone } & \multicolumn{4}{|c|}{ Wet zone } \\
\hline & & $\mathrm{n}$ & mean $\pm \mathrm{SD}$ & $\min$ & $\max$ & $\mathrm{n}$ & mean $\pm \mathrm{SD}$ & $\min$ & $\max$ \\
\hline \multirow{3}{*}{ Glom. } & Left & 5 & $0.64 \pm 0.11$ & 0.46 & 0.78 & 5 & $0.71 \pm 0.30$ & 0.30 & 0.96 \\
\hline & Right & 5 & $0.64 \pm 0.25$ & 0.36 & 0.98 & 5 & $0.74 \pm 0.15$ & 0.57 & 0.96 \\
\hline & Total & 10 & $0.64^{a} \pm 0.18$ & 0.36 & 0.98 & 10 & $0.72^{\mathrm{a}} \pm 0.23$ & 0.30 & 0.96 \\
\hline \multirow{3}{*}{ Prox.tub. } & Left & 5 & $4.45^{\mathrm{a}} \pm 2.42$ & 2.42 & 8.14 & 5 & $21.80^{\mathrm{b}} \pm 4.33$ & 15.49 & 25.42 \\
\hline & Right & 5 & $4.71^{\mathrm{a} \pm 1.61}$ & 3.32 & 7.06 & 5 & $19.30^{\mathrm{b}} \pm 3.01$ & 14.51 & 22.52 \\
\hline & Total & 10 & $4.58^{\mathrm{a} \pm 1.94}$ & 2.24 & 8.14 & 10 & $20.55^{\mathrm{b}} \pm 3.75$ & 14.51 & 25.42 \\
\hline \multirow{3}{*}{ Dist. tub. } & Left & 5 & $2.83 \pm 0.89$ & 1.70 & 3.77 & 5 & $6.73 \pm 2.40$ & 3.90 & 9.96 \\
\hline & Right & 5 & $3.35 \pm 135$ & 1.57 & 5.08 & 5 & $5.68 \pm 1.79$ & 3.31 & 8.30 \\
\hline & Total & 10 & $3.09^{\mathrm{a}} \pm 1.11$ & 1.57 & 5.08 & 10 & $6.21^{\mathrm{b}} \pm 2.07$ & 3.31 & 9.96 \\
\hline \multirow{3}{*}{ Cor. Coll. Tub. } & Left & 5 & $0.85 \pm 0.21$ & 0.54 & 1.12 & 5 & $0.69 \pm 0.28$ & 0.32 & 0.96 \\
\hline & Right & 5 & $0.89 \pm 0.20$ & 0.65 & 1.22 & 5 & $0.56 \pm 0.23$ & 0.20 & 0.81 \\
\hline & Total & 10 & $0.87^{a} \pm 0.20$ & 0.54 & 1.22 & 10 & $0.63^{b} \pm 0.25$ & 0.20 & 0.96 \\
\hline \multirow{3}{*}{ Med. Coll. duct } & Left & 5 & $0.77 \pm 0.30$ & 0.42 & 1.22 & 5 & $0.65 \pm 0.24$ & 0.29 & 0.95 \\
\hline & Right & 5 & $0.84 \pm 0.41$ & 0.37 & 1.39 & 5 & $0.67 \pm 0.25$ & 0.45 & 0.99 \\
\hline & Total & 10 & $0.80^{a} \pm 0.34$ & 0.37 & 1.39 & 10 & $0.66^{\mathrm{a}} \pm 0.23$ & 0.29 & 0.99 \\
\hline \multirow{3}{*}{$\begin{array}{l}\text { Thick limb of } \\
\text { loop of Henle }\end{array}$} & Left & 5 & $1.96 \pm 0.59$ & 1.23 & 2.85 & 5 & $3.09 \pm 0.88$ & 1.96 & 4.41 \\
\hline & Right & 5 & $2.03 \pm 0.83$ & 0.95 & 3.17 & 5 & $2.83 \pm 0.70$ & 1.64 & 3.38 \\
\hline & Total & 10 & $2.00 \mathrm{a} \pm 0.68$ & 0.95 & 3.17 & 10 & $2.96^{\mathrm{b}} \pm 0.76$ & 1.64 & 4.41 \\
\hline \multirow{3}{*}{$\begin{array}{l}\text { Thin limb of } \\
\text { loop of Henle }\end{array}$} & Left & 5 & $0.62 \pm 0.22$ & 0.43 & 1.01 & 5 & $0.53 \pm 0.27$ & 0.24 & 0.85 \\
\hline & Right & 5 & $0.69 \pm 0.37$ & 0.32 & 1.27 & 5 & $0.60 \pm 0.25$ & 0.35 & 1.04 \\
\hline & Total & 10 & $0.65^{a} \pm 0.29$ & 0.32 & 1.27 & 10 & $0.57^{\mathrm{a}} \pm 0.25$ & 0.24 & 1.04 \\
\hline \multirow{3}{*}{ Cortex } & Left & 5 & $15.16 \pm 3.59$ & 10.31 & 19.35 & 5 & $53.46 \pm 13.84$ & 36.07 & 65.99 \\
\hline & Right & 5 & $16.88 \pm 5.23$ & 9.58 & 21.47 & 5 & $46.97 \pm 5.22$ & 42.35 & 54.91 \\
\hline & Total & 10 & $16.02^{\mathrm{a} \pm 4.32}$ & 9.58 & 21.47 & 10 & $50.22^{\mathrm{b}} \pm 10.44$ & 36.07 & 65.99 \\
\hline \multirow{3}{*}{ Medulla } & Left & 5 & $3.86 \pm 1.29$ & 2.54 & 5.99 & 5 & $6.84 \pm 2.06$ & 4.10 & 9.65 \\
\hline & Right & 5 & $3.95 \pm 1.83$ & 1.78 & 6.50 & 5 & $6.48 \pm 1.76$ & 4.58 & 9.12 \\
\hline & Total & 10 & $3.91 \mathrm{a} \pm 1.49$ & 1.78 & 6.50 & 10 & $6.66^{b} \pm 1.82$ & 4.10 & 9.65 \\
\hline \multirow{3}{*}{ Kidney } & Left & 5 & $19.02 \pm 4.64$ & 12.85 & 25.34 & 5 & $60.90 \pm 15.20$ & 40.55 & 76.15 \\
\hline & Right & 5 & $20.83 \pm 6.83$ & 12.22 & 27.97 & 5 & $53.93 \pm 6.24$ & 47.39 & 62.15 \\
\hline & Total & 10 & $19.93^{\mathrm{a}} \pm 5.59$ & 12.22 & 27.97 & 10 & $57.41^{\mathrm{b}} \pm 11.55$ & 40.55 & 76.15 \\
\hline
\end{tabular}

Mean values within a rows followed by different superscript letters are significantly different $(P<0.05)$

Glomerule (Glom.); Proximal tubule (Prox. tub.); Distal tubule (Dist. tub.); Cortical Collecting Tubule (Cor. Coll. Tub.) 
Table 2: Description of the proportion of each component volume to the whole size of the kidney for left ( $\mathrm{n}=5$ ), right $(n=5)$ and total $(n=10)$ structures of the kidney in birds living in wet and arid zones

\begin{tabular}{|c|c|c|c|c|c|c|c|c|c|}
\hline \multirow{2}{*}{ Component } & & \multicolumn{4}{|c|}{ Arid zone } & \multicolumn{4}{|c|}{ Wet zone } \\
\hline & & $\mathrm{n}$ & mean $\pm \mathrm{SD}$ & $\min$ & $\max$ & $\mathrm{n}$ & mean \pm SD & $\min$ & $\max$ \\
\hline \multirow{3}{*}{ Glom./kidney } & Left & 5 & 0.030 .004 & 0.03 & 0.04 & 5 & $0.011 \pm .003$ & 0.006 & 0.013 \\
\hline & Right & 5 & 0.030 .003 & 0.03 & 0.03 & 5 & $0.013 \pm 0.002$ & 0.011 & 0.016 \\
\hline & Total & 10 & $0.03^{\mathrm{a}} \pm 0.004$ & 0.03 & 0.04 & 10 & $0.011^{\mathrm{b}} \pm 0.003$ & 0.006 & 0.013 \\
\hline \multirow{3}{*}{$\begin{array}{l}\text { Prox. Tub./ } \\
\text { kidney }\end{array}$} & Left & 5 & $0.22 \pm 0.07$ & 0.14 & 0.32 & 5 & $0.362 \pm 0.024$ & 0.324 & 0.385 \\
\hline & Right & 5 & $0.23 \pm 0.04$ & 0.17 & 0.28 & 5 & $0.357 \pm 0.038$ & 0.306 & 0.412 \\
\hline & Total & 10 & $0.22 \pm 0.05$ & 0.14 & 0.32 & 10 & $0.359 \pm 0.030$ & 0.306 & 0.412 \\
\hline \multirow{3}{*}{ Dist. Tub./kidney } & Left & 5 & $0.14 \pm 0.02$ & 0.13 & 0.19 & 5 & $0.109 \pm 0.022$ & 0.078 & 0.138 \\
\hline & Right & 5 & $0.15 \pm 0.02$ & 0.13 & 0.20 & 5 & $0.104 \pm 0.025$ & 0.066 & 0.133 \\
\hline & Total & 10 & $0.15 \pm 0.002$ & 0.13 & 0.20 & 10 & $0.106 \pm 0.022$ & 0.066 & 0.138 \\
\hline \multirow{3}{*}{$\begin{array}{l}\text { Cor. Coll. Tub./ } \\
\text { kidney }\end{array}$} & Left & 5 & $0.04 \pm 0.007$ & 0.04 & 0.06 & 5 & $0.011 \pm 0.004$ & 0.007 & 0.019 \\
\hline & Right & 5 & $0.04 \pm 0.009$ & 0.04 & 0.06 & 5 & $0.010 \pm 0.004$ & 0.003 & 0.014 \\
\hline & Total & 10 & $0.04 \pm 0.007$ & 0.04 & 0.06 & 10 & $0.011 \pm 0.004$ & 0.003 & 0.019 \\
\hline \multirow{3}{*}{$\begin{array}{l}\text { Med. Coll. duct/ } \\
\text { kidney }\end{array}$} & Left & 5 & $0.03 \pm 0.006$ & 0.03 & 0.05 & 5 & $0.010 \pm 0.003$ & 0.007 & 0.016 \\
\hline & Right & 5 & $0.03 \pm 0.009$ & 0.02 & 0.05 & 5 & $0.012 \pm 0.004$ & 0.007 & 0.018 \\
\hline & Total & 10 & $0.03 \pm 0.007$ & 0.02 & 0.05 & 10 & $0.011 \pm 0.004$ & 0.007 & 0.018 \\
\hline \multirow{3}{*}{$\begin{array}{l}\text { Thick limb of loop } \\
\text { of Henle / kidney }\end{array}$} & Left & 5 & $0.10 \pm 0.01$ & 0.09 & 0.13 & 5 & $0.051 \pm 0.009$ & 0.042 & 0.065 \\
\hline & Right & 5 & $0.09 \pm 0.02$ & 0.06 & 0.13 & 5 & $0.052 \pm 0.010$ & 0.034 & 0.061 \\
\hline & Total & 10 & $0.10 \pm 0.01$ & 0.06 & 0.13 & 10 & $0.051 \pm 0.009$ & 0.034 & 0.065 \\
\hline \multirow{3}{*}{$\begin{array}{l}\text { Thin limb of loop } \\
\text { of Henle / kidney }\end{array}$} & Left & 5 & $0.03 \pm 0.06$ & 0.02 & 0.04 & 5 & $0.008 \pm 0.004$ & 0.003 & 0.013 \\
\hline & Right & 5 & $0.03 \pm 0.008$ & 0.02 & 0.05 & 5 & $0.011 \pm 0.004$ & 0.005 & 0.017 \\
\hline & Total & 10 & $0.03 \pm 0.007$ & 0.02 & 0.05 & 10 & $0.010 \pm 0.004$ & 0.003 & 0.017 \\
\hline \multirow{3}{*}{ Cortex/kidney } & Left & 5 & $0.7 \pm 90.03$ & 0.76 & 0.84 & 5 & $0.876 \pm 0.026$ & 0.838 & 0.909 \\
\hline & Right & 5 & $0.81 \pm 0.04$ & 0.77 & 0.88 & 5 & $0.871 \pm 0.024$ & 0.838 & 0.893 \\
\hline & Total & 10 & $0.80 \pm 0.03$ & 0.76 & 0.88 & 10 & $0.874 \pm 0.024$ & 0.838 & 0.909 \\
\hline \multirow{3}{*}{ Medulla/kidney } & Left & 5 & $0.20 \pm 0.03$ & 0.16 & 0.24 & 5 & $0.113 \pm 0.026$ & 0.080 & 0.149 \\
\hline & Right & 5 & $0.18 \pm 0.04$ & 0.12 & 0.23 & 5 & $0.119 \pm 0.025$ & 0.096 & 0.155 \\
\hline & Total & 10 & $0.19 \pm 0.03$ & 0.12 & 0.24 & 10 & $0.116 \pm 0.024$ & 0.080 & 0.155 \\
\hline
\end{tabular}

Mean values within a rows followed by different superscript letters are significantly different $(\mathrm{P}<0.05)$ 
of a proximal segment and a distal papillary duct covered by the columnar epithelium. The cytoplasm of each cell contained a basal nucleus and mucopolysaccharides. The latter fuses dendritically as they traverse a medullary unit, and eventually forms ureteric branches, draining directly into the ureter. Therefore, each medullary cone terminates in a single branch of the ureter (ureteric branch). Furthermore, the cells of the ureteric branch contained mucopolysaccharide (Figs. 5, 6).

Tables 1 and 2 present the Mean \pm standard deviation of the absolute volume of the structures within the left and right kidneys, and proportion of the each structure volume to the whole size of the kidney for wet and arid zone birds. The absolute volume of the structures within the kidneys, and the proportion of each component volume to the whole size of the kidney were not significantly different between the right and left kidneys of birds living in wet and arid zones $(p>0.05)$. The volume of the whole kidney $(\mathrm{p}<0.001)$ in wet zone birds was larger than that in arid zone birds (Table 1). Furthermore, the volume proportion of proximal tubule and cortex to the whole size of the kidney in wet zone birds was higher than that in arid zone birds. However, the volume proportion of the medulla, distal tubule, cortical collecting tubule, medullary collecting duct and thin limb of loop of Henle to the whole size of the kidney in arid zone birds was higher than that in wet zone birds ( $\leq 0.001$; Table 2).

\section{Discussion}

Histologically, the sparrows' kidneys consisted of two zones, the cortex and the medulla. The cortex made up a vast area of the kidney with only a small portion being medulla. There was no difference between the histological structure of the sparrow's kidney in wet and arid zones. This feature is similar to that in rock dove, collared dove and owl (7).

It seems that the avian medullary cones are structurally similar (analogous) to the outer medulla of mammals' kidneys (8). The luminal surface area of the proximal tubule was enhanced by a thick layer of microvilli forming a brush border. Increase of the volume and surface area of the brush border may lead to a greater quantity of glomerular filtrate of the proximal tubule (2). It is accepted that the wide intercellular spaces coupled with the extensive cell membrane infolding in proximal tubule is the characteristic of cells having considerable ion and water reabsorption capacity (9). For example, in house geckos (Hemidactylus sp.), under hydrated conditions, $80 \%$ of the filtered water and ions are reabsorbed by elaborated cell membrane infolding, whereas in horned lizard Phrynosoma cornutum and the Galapagos iguanid lizard Tropidurus sp. with no cell membrane infolding, reabsorbtion is approximately $50 \%$ of the filtered water and ions (10). In mammals, approximately $70 \%$ of all ions are reabsorbed in the proximal tubule (11). The absorption of the proximal tubule in avian, depending on active reabsorption, is approximately $70 \%$ of the filtered volume of water (1). In the avian nephron, absorption of sodium chloride from the distal tubule in some cases, may proceed without water reabsorption and increase the cranial concentration gradient along the length of the nephron tubule, thereby allowing the water to be distally reabsorbed along the nephron at the medullary collecting ducts. The distal tubule in the bird's nephron reabsorbs water passively and reabsorbs sodium chloride actively from the nephron tubule as the mammalian's nephron (12). This additional reabsorption helps to conserve the fluid that might otherwise be excreted. Hence, the act of reabsorption by the distal tubule saves both water and solutes (13). The macula densa (MD) in sparrows was not as well developed as in mammals, in which they did not have taller cells, but resembled closely to the macula densa cells found in honeyeaters birds (3), G. domesticus (14), C. japonica (15) and the common starling Sturnus vulgaris (16). The avian cells possess some characteristics of mammalian's MD cells and they are distinguishable from the cells in adjacent portions of the distal tubule. The Golgi system in the avian cells is from apex to the nucleus. The cells in avian MD sites can be considered structurally transitional between the mammal's typical MD cells in mammals and the ordinary cells of the distal tubule (15).

The cortical collecting tubule was covered by the cuboidal epithelium. Each cell contained a basal nucleus and the characteristics of cells having high ion and water reabsorption capacity (9). As with the distal tubules, the cortical collecting tubules also play a role in producing concentrated urine by reabsorbing the water from the tubular lumen. In addition, they are also known to secrete 
the mucin, which may help to clear the kidney from the uric acid (13). Since the uric acid is a means of excreting the solutes with minimal water loss, it might be expected that arid zone birds produce more uric acid than wet zone birds as a water conservation strategy.

The countercurrent multiplier mechanism operates between the descending and ascending limbs of Henle via recycling a single solute $(\mathrm{NaC})$ with no water accompaniment, forming an osmotic gradient along the medullary cone (17). In sparrows, the nephron tubules were regularly arranged for the entire length of the medulla, with the thick and thin limbs of loop of Henle separated by the collecting ducts. This situation is different from the arrangement pattern reported in muscicapid passerines, where the tubules were orderly arranged only in the superficial areas of the medulla, and randomly deeper within the medulla $(18,19,20,21)$. The functional significance of the ordered medullary tubule arrangement in passerines is unknown. The separation of the thick and thin limbs of loop of Henle by the collecting ducts appears to complicate the current theory of production of concentrated urine in birds (21). The wide intercellular spaces and few mitochondria in the epithelium of the thin limb of loop of Henle are typical of leaky epitheliums transporting the solutes passively (3). This study found that the volume of the thin limb of loop of Henle was greater in arid zone birds. This indicated that the loops of Henle in arid zone sparrows were longer than those in wet zone sparrows. It is concluded that the loops of Henle are the important areas of water reabsorption. On the contrary, the epithelial cells of the thick limb of loop of Henle in honeyeaters contained more mitochondria, and individual cells were separated by narrow intercellular spaces (3). The avian and mammalian's thick limbs are similar in diameter, but avian thin limbs are typically wider (20). In mammals, generally, longer loops of Henle are associated with a high urine concentrating ability $(22,23)$. The role of the medullary collecting duct is reabsorption of water and possibly some sodium from the tubule (24). It seems that there are no differences in the ultrastructural anatomy of the sparrows' nephrons. The proximal tubules contain both narrow and wide intercellular spaces filled with interdigitations of the basolateral membrane. The thin limbs of loop of Henle contain the very wide intercellular spaces, which are absent in the thick limbs of loop of Henle. The distal tubule cells contain short, apical microvilli and infolding of the basolateral membrane. In cross-section, the medullary cones of all birds exhibit an outer ring of thick limbs of loop of Henle surrounding an inner ring of collecting ducts, which in turn surrounds a central core of thin limbs of loop of Henle. The Savannah Sparrow has a significant higher volume of medulla compared to wet zone species. Within the medulla, the Savannah Sparrow has a significant higher volume and surface area of capillaries, and a significant higher surface area of thick limbs of loop of Henle and collecting ducts than wet zone species. The data suggest that the salt marsh Savannah Sparrow has the renal morphology necessary to produce more high concentrated urine than wet zone species. A bird living in a salt marsh environment might be expected to concentrate its urine more than wet zone birds owing to limited availability of fresh water and a large amount of potential salt in its diet (24).

The absolute volume of the structures of the kidneys in sparrows is not significantly different between the right and left kidneys. The volume of the whole kidney $(p<0.001)$ in wet zone birds was larger than that in arid zone birds. Furthermore, the volume proportion of the proximal tubule and the cortex to the whole kidney size was higher in wet zone birds than in arid zone ones. However, the volume proportion of the medulla, distal tubule, cortical collecting tubule, medullary collecting duct and thin limb of loop of Henle to the whole size of the kidney was higher in birds living in the arid zone environment $(\mathrm{p} \leq 0.001)$. This feature indicates that the arid zone bird species have a higher ability to conserve the water by producing concentrated urine.

We found that the structure of wet zone sparrows' kidney contained a higher proportion of cortex, whereas in arid zone sparrows, the higher proportion was for the medulla. By different environmental and dietary restrictions, the renal concentrating ability of birds may vary (25). Possible differences in the urinary concentrating ability of species from different zones may be due to differences in the proportion of cortex and medulla. Previous studies demonstrated that arid zone birds had a high volume of renal medulla than wet zone birds $(26,2,27,28)$. Similar results have been found for honeyeater birds (3), the mesic inhabiting white-rumped munia (Lonchura 
striata), the collared turtle dove (Streptopelia decaocta), and several species of aquatic birds (28). Birds inhabiting an arid environment and having a largely insectivorous diet have a greater volume of medulla than those inhabiting mesic environments and having a nectarivorous diet (27). The volume of the kidney increased in proportion to the body weight, and these two parameters were strongly correlated with each other. A strong correlation between the kidney weight and body weight has been reported in avian species. The volume proportions of the cortex and medulla vary according to the bird's order, body size and environment. High renal concentrating ability improves the efficiency of renal conservation of water, and thus the species with larger proportions of renal medulla should have effective conservation of water. The quantitative structural characteristics of the avian kidney appear to be influenced by several factors, since the kidney volume per body weight in grams, and the volume proportions of the cortex and medulla can be correlated with the order, body size and habitat. Furthermore, a relatively large medulla seems to be the adaptive advantage of species, which have to mitigate the water scarcity or excessive evaporative water loss by maximum renal water conservation (28).

The absolute volume of the structures within the house sparrow's kidneys is not significantly different in different seasons. Thus, kidney morphology may not be affected by seasonal changes (13).

\section{Acknowledgements}

The authors declare that they have no conflict of interests.

This research was supported by a grant (No. 3.28795, 3.28801) from the Research Council of Ferdowsi University of Mashhad.

\section{References}

1. Reece WO. Dukes' physiology of domestic animals. $12^{\text {th }}$ ed. Ithaca : Cornell University Press, 2004.

2. Braun EJ, Dantzler WH. Vertebrate renal system. In: Dantzler WH, ed. Handbook of physiology: comparative physiology. New York : Oxford University Press, 1997: 481-576.

3. Casotti G. Effects of season on kidney mor- phology in House sparrows. J Exp Biol 2001; 204: 1201-6.

4. Nicolson SW, Worswick PV. Sodium and potassium concentrations in floral nectars in relation to foraging by honeybees. S Afr J Zool 1990; 25: 93-6.

5. Mayhew TM. The new stereological methods for interpreting functional morphology from slices of cells and organs. Exp Physiol 1991; 76: 639-65.

6. Gundersen HJG, Bendtsen TF, Korbo L, et al. Some new, simple and efficient stereological methods and their use in pathological research and diagnosis. Acta Pathol Microbiol Immunol Scand 1988; 96: 379-94.

7. Nabipour A, Alishahi E, Asadian M. Some histological and physiological features of avian kidney. J Appl Anim Res 2009; 36: 195-8.

8. Casotti G, Lindberg KK, Braun EJ. Functional morphology of the avian medullary cone. Am J Physiol Regul Integr Comp Physiol 2000; 279(5): R1722-30.

9. Cunningham JG, Klein BG. Textbook of veterinary physiology. St. Louis : Saunders, 2007: 537-64.

10. Roberts JS, Schmidt-Nielsen B. Renal ultrastructure and excretion of salt and water by three terrestrial lizards. Am J Physiol 1966; 211 : 476-86.

11. Goldstein DL, Braun EJ. Proportions of mammalian-type and reptilian-type nephrons in the kidneys of two passerine birds. J Morphol 1986; 187: 173-9.

12. Casotti G, Richardson KC. A stereological analysis of kidney structure of honeyeater birds (Meliphagidae) inhabiting either arid or wet environments. J Anat 1992; 180: 281-8.

13. Casotti G, Richardson KC. A qualitative analysis of the kidney structure of Meliphagid honeyeaters from wet and arid environments. J Anat 1993; 182: 239-47.

14. Morild I, Mowinckel R, Bohle A, Christensen JA. The juxtaglomerular apparatus in the avian kidney. Cell Tiss Res 1985; 240: 209-14.

15. Ogawa $M$, Sokabe $H$. The macula densa site of the avian kidney. Z Zellforsch Mikrosk Anat 1971; 120: 29-36.

16. Nicholson JK. The microanatomy of the distal tubules, collecting tubules and collecting ducts of the starling kidney. J Anat 1982; 134: 11-23.

17. Nishimura $H$. Urine concentration and avian aquaporin water channels. Pflugers Arch 2008; 456: 755-68. 
18. Laverty G, Dantzler WH. Micropuncture of superficial nephrons in avian (Sturnus vulgaris) kidney. Am J Physiol 1982; 243: F561-9.

19. Johnson OW. Urinary organs. In: King AS, McLelland J, eds. Form and function in birds. Vol. 1. New York : Academic Press, 1979: 183-35.

20. Jonson OW, Mugaas JN. Some histological features of avian kidneys. Am J Anat 2005; 127: 423-35.

21. Nishimura H, Koseki C, Imai M, Braun EJ. Sodium chloride and water transport in the thin descending limb of Henle of the quail. Am J Physiol 1989; 257: F994-1002.

22. Schmidt-Nielsen B, O'dell R. Structure and concentrating mechanism in the mammalian kidney. Am J Physiol 1961; 200: 1119-24.

23. Sperber I. Studies on the mammalian kid- ney. Zool Bidrag Uppsala 1944; 22: 249-435.

24. Casotti G, Braun EJ. Renal anatomy in sparrows from different environments. J Morphol 2000; 243: 283-91.

25. Braun EJ. Renal osmoregulation. In: Epple A, Stetson MH, eds. Avian endocrinology. New York : Academic Press, 1980: 499-516.

26. Casotti G, Richardson KC. Ecomorphological constraints imposed by the kidney component measurements in honeyeater birds inhabiting different environments. J Zool 1993; 231: 611-25.

27. Casotti G, Beuchat CA, Braun EJ. Morphology of the kidney in a nectarivorous bird, the Anna's hummingbird, Calypte anna. J Zool 1998; 244: $175-84$.

28. Warui CN. Light microscopic morphology of the kidneys of fourt

\title{
HISTOLOŠKA IN STEREOLOŠKA ŠTUDIJA LEDVIC VRABCEV, ŽIVEČIH V VLAŽNIH IN SUHIH OBMOČJIH
}

\author{
M. Rezaei, Z. Masoumi, A. Nabipour, M. Azizzadeh, M.Behnam-Rasouli
}

Povzetek: V opisani raziskavi smo primerjali strukturo ledvic vrabcev, ki živijo v vlažnih in sušnih območjih. Izvedena je bila stereološka raziskava, s katero smo količinsko opredelili različne tkivne strukture v ptičjih ledvicah. Zbrali smo vzorce 10 samic vrabcev, ki živijo v vlažnih in sušnih območjih. Pred nadaljnjo histološko obdelavo vzorcev smo izmerili dolžino ledvic. Pripravljene so bile prečne serijske rezine ledvic debeline $5 \mu \mathrm{m}$. Rezine so bile obarvane s hematoksilinom in eozinom (barvanje H\&E) ter s PAS histokemijsko reakcijo $z$ dodatkom alcianskega modrila (PAS-AL). Ledvice vrabcev so večinoma sestavljala področja skorje in manjši deli sredice. Sredico so sestavljali stožci različnih dolžin, ki so bili naključno razporejeni znotraj ledvice. Središčne cevke nefrona so potekale ena ob drugi. Debelejši in tanjši deli zanke nefrona so bili ločeni z zbirnimi cevkami. Histološka zgradba ledvic, absolutna prostornina ledvic in sestavni deli nefrona so bili kvantitativno ovrednoteni. Absolutna prostornina struktur se med levo in desno ledvico ni značilno razlikovala. Prostornina celotne ledvice vrabcev v vlažnem območju je bila večja od prostornine ledvic vrabcev iz sušnega področja $(p<0,001)$. Poleg tega je bil prostorninski delež proksimalne cevke in področje skorje v primerjavi s celotno velikostjo ledvic večji pri pticah iz sušnega področja kot pri pticah iz vlažnega področja. Prostorninski delež sredice, distalne cevke, zbirne cevke v skorji, zbirnega kanala v sredici in tankega dela zanke nefrona v celotni velikosti ledvic pa je bil višji pri vrabcih iz vlažnih področij kot pri vrabcih iz sušnih področij $(p \leq 0,001)$. Opisane značilnosti ledvic kažejo na to, da bi lahko imele ptice iz sušnih območij večjo sposobnost ohranjanja vode s proizvodnjo koncentriranega urina.

Ključne besede: vrabec; stereologija; histologija; ledvica; okolje 